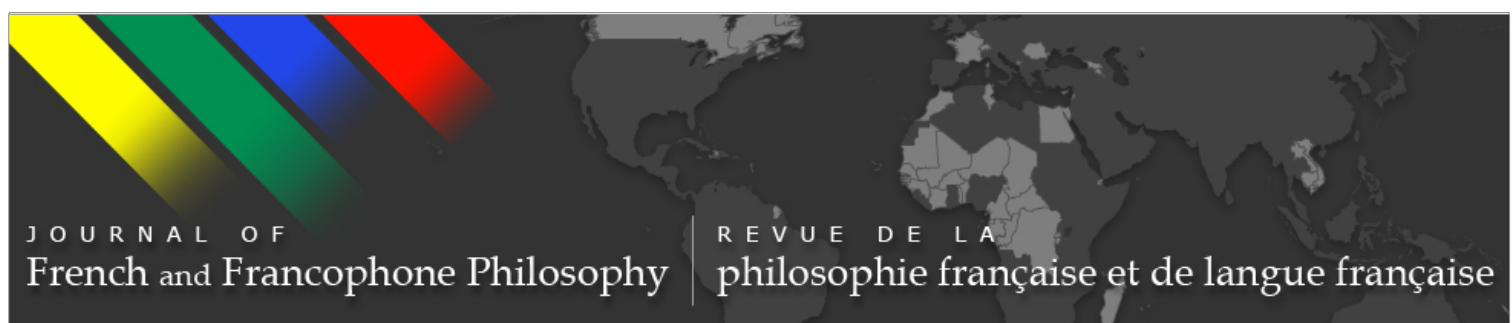

\title{
New Forms of Revolt
}

\section{Julia Kristeva}

Journal of French and Francophone Philosophy - Revue de la philosophie française et de langue française, Vol XXII, No 2 (2014) pp 1-19

\author{
Vol XXII, No 2 (2014) \\ ISSN 1936-6280 (print) \\ ISSN 2155-1162 (online) \\ DOI 10.5195/jffp.2014.650 \\ www.jffp.org
}

\section{(oc) BY-NG-ND}

This work is licensed under a Creative Commons Attribution-Noncommercial-No Derivative Works 3.0 United States License.

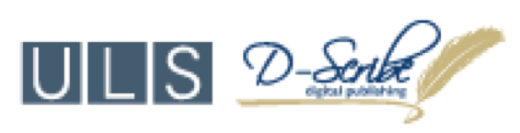

This journal is operated by the University Library System of the University of Pittsburgh as part of its D-Scribe Digital Publishing Program, and is co-sponsored by the University of Pittsburgh Press 


\title{
New Forms of Revolt
}

\author{
Julia Kristeva
}

Université Paris Diderot - Paris 7

\section{An Inner Experience}

Popular uprisings, indignant youth, toppled dictators, oligarchic presidents dismissed, hopes dashed, liberties crushed in prisons, fixed trials, and bloodbaths. How are we to read these images? Could revolt, or what is called "riot" on the Web, be waking humanity from its dream of hyperconnectedness? Or could it just be a trick played on us so that the culture of spectacle can last longer? But what "revolt" are we talking about? Is it even possible, in these times of widespread misery, endemic debt, austerity and unemployment, when local wars can turn into global ones and when the melting of the icecaps is ready to flood us?

I wrote L'Avenir d'une révolte (1998), translated as The Future of Revolt in 2002, shortly after The Sense and Non-Sense of Revolt (1996) and Intimate Revolt (1997), about fifteen years ago. ${ }^{1}$ France remains proud of its memory and its exceptional culture, but it is also increasingly disappointed by the plans and promises of politics and it is becoming absentionist in an aging Europe. But France remains animated by an unquenchable thirst for the freedom of thought, which is expressed in the brilliance of the French language and the passion for Republican debate.

I was listening then and am still listening now to my analysands: regardless of their gender, these people are experiencing a personal crisis or a crisis plain and simple, and they are opening up — in well-worn words their eternal return and maybe their rebirth. A new type of angry person has taken up the path of intimate revolt. They are the new realists who, as we used to say in May 1968, want the impossible. Their revolt appears to me as the visible side of a reassessment of the religious domain, which is called inner experience. This inner experience continues to assert itself timidly, secretly but yet distinctly below the surface of images, elements of language and tensions of identity. It is this revolt, which goes against the tide of the

Journal of French and Francophone Philosophy | Revue de la philosophie française et de langue française Vol XXII, No 2 (2014) | www.jffp.org | DOI 10.5195/jffp.2014.650 
oppression and fear of unsolvable crisis as well as idealistic enchantment, that I examine in the following pages, which have been translated in numerous languages. Their meaning now comes back to me like an echo sent back by new, unsuspected readers.

I am thinking, for instance, of an American researcher who was analyzing the traps and benefits of political bipartisanship and who turned to European or so-called "Continental" philosophy in order to inquire into "values" rather than exploring data. I am thinking of a Chinese lawyer and a Chinese artist who were awarded the Simone de Beauvoir Award for women's freedom. While partaking in the economic rise of China, they are also running the risk of rebelling and are demanding the application of "women's rights", at a time when human rights are still not being widely recognised. I am also thinking of the democrats who took part in the "Arab Spring," before the return of the defeated Islamic fundamentalists. I am thinking of the Chilean student who waved a Spanish translation of my writings on revolt outside his institution, which was on strike, and who displayed a poster that read "The University in Revolt," in response to drastic funding cuts in education. Finally, I am thinking of the Syrian psychoanalysts who are attempting an astonishing transvaluation of their tradition. They are resisting dictatorship by creating "group psychotherapies against fear"- and they are refining their translations of Freud's writings, borrowing from the lexicon of Arab mysticism.

This new species of rebels (revoltés) are enraged, but they have not lost the decisive and specific meaning of revolt. Each and every one of them is involved in a difficult and often tiresome life and carries out a risky struggle. Yet, they do share something new, something that has perhaps been there all the while, but that can now be confessed to and even redeemed. They are discovering through their experiences that there is no answer to social, historic and political impasses without a radical inner experience; an inner experience that is demanding, unique, and able to appropriate the complexity of the past in order to approach the present and the future.

This inner experience is meant to escape the shortsightedness of the technicians of political governance, to fight against the fundamentalism that seeks to eliminate corruption but starts by repressing fundamental liberties. This inner experience is also meant to avoid the nonsensical and vengeful rejection, which is both symmetrical and powerless, that denounces one's opponent without being able to propose a sensible alternative. It is not enough to have a plan. It is necessary to have men and women with inner experiences that are unique, inquisitive, and uncompromising. It is on this condition alone that they can be reformers. It is necessary to have men and women who know how to pass on and share a language of revolt. It is only at this price that they can be innovative.

Journal of French and Francophone Philosophy | Revue de la philosophie française et de langue française Vol XXII, No 2 (2014) | http://www.jffp.org | DOI 10.5195/jffp.2014.650 
Poetry has always been able to proclaim the desire for free will, by restoring words to memory and thereby extracting a sense of time. In those eras that are vaguely felt to be in decline or at least in a state of suspension, questioning remains the only possible thought: it is an indication of a life that is simply living. Intimacy is not the new prison. Its need for connection might, one day, initiate another politics. Today, mental life knows that it will only be saved if it gives itself the time and space of revolt: to break, to remember, to re-do. From prayer to dialogue, through art and analysis, the crucial event is always the great infinitesimal emancipation: to recommence endlessly. Without it, all that globalization would have to do is to calculate growth rates and genetic probabilities. Truths, including scientific ones, may well be illusions, but they have the future in front of them. In contrast with certainties and beliefs, permanent revolt is this questioning of the self, of everything and of nothingness, which no longer seems to have any place to occur. Be that as it may, if there is still time, let us wager on the future of revolt. As Albert Camus said, "I revolt, therefore we are." Or rather: "I revolt, therefore we are to come." This is an enlightening and long-lasting experience.

\section{What Revolt Today?}

For at least two centuries, the word "revolt", with its rich and complex etymology, has had a political meaning. ${ }^{2}$ Today we understand revolt as a challenge to pre-established norms, values, and powers. Ever since the French Revolution, "political revolt" has been the secular version of the negativity that is characteristic of the life of conscience when it attempts to remain faithful to its internal logic. A synonym of dignity, revolt is our mysticism.

But we are increasingly aware that what is called the "new world order" - whose democratic advantages no longer need to be praised, despite its risks and even its dead-ends in the East - is not propitious to this revolt. Against whom does one revolt if power and values are vacant or corrupt? Or, even more seriously, who can revolt if one is increasingly reduced to a conglomerate of organs, if one is no longer a "subject" but a "patrimonial person", endowed not only with a financial patrimony but also a genetic or physiological, free at best only to channel-surf? If I exaggerate and simplify the present state of affairs, it is only to better highlight what we all perceive. It is not only the case that political revolt has become entangled in trade-offs between parties, whose ideological differences are less and less obvious to us; an essential ingredient of European culture - a culture fashioned by doubt and critique - is losing its moral and aesthetic significance. When it exists, it is marginalized as an ornamental alibi tolerated by the society of the spectacle, when it is not simply engulfed and made impossible by "entertainment culture," "performance culture," and 
"show-business culture" (culture-show). The use of Anglicisms here conveys the dynamics at work.

At the risk of aggravating my image as someone who willingly depicts and even enjoys exaggerating the seriousness of the present state of affairs, I would like to discuss some aspects of my novel, Possessions. Against the backdrop of a detective story, the body of a beheaded woman is discovered: she was Gloria Harrison, a translator by profession and the mother of a difficult child. The reader discovers that not one but several characters are in fact responsible for the murder, before the final beheading happened. I put a lot of myself into this depiction of female and maternal suffering that sums up the difficulty of being a woman. I am the beheaded woman. I am also the female investigator in charge, alongside detective superintendant, Northrop Rilsky. Another woman, Stephanie Delacour, is a journalist from Paris. It is still possible to carry out an investigation in the virtual, Mafia-dominated world that is Santa Barbara. "You can know": that is basically what the reader of detective novels is told. Indeed, in this popular genre the possibility to question remains alive. Could that be the reason why, though people no longer read, they still read detective novels: is the zero degree of questioning's aptitude for judgment our only remaining safeguard against the "banality of evil"? To my mind, Possessions, among many other novels, is a humble form of revolt. But are other, higher forms of revolt, really any more effective?

Furthermore, the female world allows me to suggest an alternative to a robotizing and spectacular society that damages the culture of revolt: this alternative is, quite simply, sensible intimacy. Possessing their passions and sensibilities, some human beings nonetheless continue to ask themselves questions. I am convinced that, after all the more or less promising projects and slogans that were launched by feminist movements in the seventies, the arrival of women on the front of the moral and social stage will have the effect of revalorizing sensible experience, as an antidote to technical calculation. The immense responsibility of women for the survival of the species - how can we preserve the freedom of our bodies while at the same time ensuring that the best conditions are provided for the lives of our children? - goes hand in hand with this rehabilitation of the sensible. The novel is the privileged terrain for such an exploration and for its communication to the greatest number. Alongside and in addition to the culture of the image - its seduction, its swiftness, its brutality, and its easy accessibility - the culture of words, the narrative and the place it reserves for meditation, seems to me to be a type of minimal revolt. It may not be very much, but are you sure that we have not reached a point of no return, from which we will have to return to the little things - infinitesimal revolts — in order to preserve the life of the mind and of the species?

Revolt, then, as return/turning back/displacement/change, constitutes the internal logic of a certain culture that I would like to revive here and

Journal of French and Francophone Philosophy | Revue de la philosophie française et de langue française

Vol XXII, No 2 (2014) | http://www.jffp.org | DOI 10.5195/jffp.2014.650 
whose acuity seems quite threatened these days. But let us return once again to the meaning of this revolt, which seems to me to indicate what is most alive and promising about our culture.

\section{Similarities and Differences with the "Retrospective Return"}

Ever since Socrates and Plato and even more explicitly so in Christian theology, humans have been invited to "return". Some of you may still retain a trace of this, if not the practice. This is notably the aim of Saint Augustine's repetition, which is based on the retrospective link to the Creator's already-there: the possibility of questioning one's own being, searching for oneself (se quaerere: 'quaesto mihi factus sum'), is offered by this aptitude to "re-turn", which is also simultaneously recollection, interrogation, and thought.

Yet technological development has favored the knowledge of stable values, to the detriment of thought as return and as search (as repetition, as se quaerere, "going in search of oneself"). Besides, the secularization of Christianity, as well as its own intrinsic tendencies toward stabilization and reconciliation in the immutability of being, have depreciated - when they have not invalidated or made impossible - this "struggle" with the world and with oneself that also characterizes Christian eschatology.

Subsequently, the questioning of values turned into nihilism. By "nihilism," I mean the rejection of old values in favour of a cult of new values that are unquestioned. What was taken as a "revolt" or a "revolution" for the past two centuries, particularly in politics and its accompanying ideologies, has most often been the abandonment of retrospective questioning in favour of an outright rejection of the old, so that new dogmas can take its place.

Generally, when the media uses the word "revolt," what is generally meant is nothing other than this nihilistic suspension of questioning in favor of so-called new values which, precisely as "values," have forgotten to question themselves, and as a result, have essentially betrayed the meaning of the re-volt that I am trying to make you appreciate here. The nihilist is not a man in revolt, in the sense I defined the term in Sense and Non-Sense of Revolt and Intimate Revolt. The pseudo-rebellious nihilist is, in fact, someone who is reconciled by the stability of new values. And this stability, which is illusory, turns out to be deadly and totalitarian. I cannot stress enough the fact that totalitarianism is the result of a certain fixation of revolt precisely in terms of its betrayal, namely, the suspension of retrospective return, which amounts to a suspension of thought. Hannah Arendt has brilliantly developed this elsewhere. ${ }^{3}$

I am therefore seeking experiences in which this work of revolt, which opens psychical life to infinite re-creation, continues and reoccurs, even at

Journal of French and Francophone Philosophy | Revue de la philosophie française et de langue française 
the price of errors and dead-ends. Indeed, we should not delude ourselves: it is not enough to revive the permanence of revolt, which technology may have inhibited, in order to secure happiness or some sort of serene stability of being. Revolt exposes the speaking subject to an unbearable conflict, and our century has assumed the daunting privilege of manifesting the necessary enjoyment (jouissance) and the morbid dead-ends associated with that conflict. But this occurs in an altogether different way from the nihilist who is focused on the celebration of an unmitigated rejection of the "old" or on the unflinching positivity inspired by the "new."

So here we are: we can either renounce revolt by returning to "old values" or even "new" ones that do not look back on themselves and do not question themselves, or on the contrary, we can persevere and relentlessly recommence the retrospective return in order to go to the limits of the representable/the thinkable/the bearable: to the point of "possession." These limits have been made evident by some advances of the culture of our century.

We should note that the revolt of modern man is not a mere resumption of the retrospective link that is the basis of the inner space of the Christian man, who is reassured in his quest which is completed by a return to the summum esse. While sharing the path of retroactive questioning, modern man comes to an irreconcilable conflict. Although it may have been produced in the margins of art or the mysticism of the past, this conflict never reached the scope or paroxysm experienced in modernity.

Just as the concept of "process" distinguishes modern history from that of antiquity, based on the destiny and genius of great men, the concept of "self-organization" is specific to contemporary history, which in our century moves from one crisis to the next. Similarly, I contend that the concept of man in revolt distinguishes the modern man from both the Christian man, reconciled with God ("coram Deo"), and the nihilist, who is his enraged but symmetrical opposite.

\section{Psychoanalysis as Revolt}

In what sense is revolt as we understand it - along with Freud, who points to the diabolical unconscious, and some contemporary writers who explore borderline cases of the psyche - distinguishable from the retrospective relationship of tendere esse with the "not yet" and the "no longer"? Let us venture an initial reply: revolt is distinguished by the particular fact that the tension toward unity, being, or the authority of the law (although still at work in the modern revolt) is accompanied more than ever by centrifugal forces of dissolution and dispersion.

Journal of French and Francophone Philosophy | Revue de la philosophie française et de langue française

Vol XXII, No 2 (2014) | http://www.jffp.org | DOI 10.5195/jffp.2014.650 
Furthermore, this conflict leads to enjoyment (jouissance), which is not simply a narcissistic or egoistic whim of those who are spoiled by consumer society or the society of the spectacle. The jouissance at stake here - and this is where Freud demonstrates how radical he is- is indispensible to keeping the psyche alive; it is indispensible to the faculty of representation and to the questioning that is specific to human beings. In this sense, Freud's discovery of the unconscious was the new Archimedean point - of the psyche as always already dependent on the Other and the other - that constituted the privileged location where life could find its meaning. This is possible if and only if the psyche is capable of revolt. It is even on this ground that Freud founded psychoanalysis as an invitation to anamnesis, with the aim of a rebirth, or in other words, a psychical restructuring.

Through a narrative of free association and in the rejuvenating revolt with and against the old law (familial taboos, superego, ideals, Oedipal or narcissistic limits, etc.), one's singular autonomy emerges, along with one's renewed link to the other. But this other "Freudian palace of memory" that psychoanalysis revisits and transforms was not perceived by Hannah Arendt, who praised Saint Augustine's palace of memory but dismissed psychology and psychoanalysis, which in her eyes were sciences of "the general."

\section{Regaining the Sense of the Negative}

The modern age, which I will date from the French Revolution, for the sake of this argument, valued the negative part of this retrospective return. Personal or collective experience became an experience of conflict or of contradiction. Being itself is wrought by nothingness, philosophy essentially says, from Hegel to Heidegger and Sartre, although in different ways.

This co-presence of nothingness with being takes a dialectical form in Hegel.

Starting with his text What is Metaphysics? (1929), Heidegger makes a distinction between the negation internal to judgment and a nothingness that annihilates differently from the way thought does: it is in sensation and anxiety that the philosopher will seek the nuclear forms of what he calls a repulsion, which is a characteristic feature of the human as a reject, an outcast of being. Dasein is a repulsion; "ek-stasy" is another word for "abjection." Has this similarity been given as much thought as it deserves?

In Being and Nothingness (1943), Sartre relies on this difference between the negation proper to thought and a primordial annihilation/nothingness. But rather than insisting on re-pulsion, he emphasizes freedom which ultimately makes him more Hegelian than Heideggerian, as much in his philosophy as in his political anarchism.

Journal of French and Francophone Philosophy | Revue de la philosophie française et de langue française 
If I am re-reading these texts today and if I am asking you to read them again with me, it is because they bear witness to a unique moment in Western thought, the moment when the "retrospective return" - that is, the knowing subject's questioning of himself and his truth - leads to nothing less than a familiarity with psychosis. There is an annihilating force (Kraft) behind the concept, whose disquieting movement (poussée) must be absorbed by the concept (Hegel), as well as the feeling of dissociation or repulsion in Heidegger and even Sartre's "pre-judicative nothingness" that fuels his notion of freedom as radical violence and as a questioning of all identity, faith, and law. All these advances, when confronted with human realities to make their logic accessible, come up against a psychical reality that endangers consciousness and exposes it to the pulse of being. This fades away the borders between subject and object; it is an assault of the drives. Language becomes tonality (Stimmung), the memory of being, the music of the body and of matter. Heidegger seeks to capture this near psychosis, by respectfully visiting the work of Hölderlin. Sartre flees it by holding on to a totalizing and translucid consciousness, for whom Flaubert, "the family idiot", and Genet, "actor and martyr" - in the neghborhood of melancholy and perversion, through style and play - offer a better hold on reason and humanism than the radical destruction performed by Artaud.

It may be surprising to maintain that the psychoanalytic movement inaugurated by Freud belongs to this interrogation into nothingness and negativity. I am not talking about American psychoanalysis which is dominated by Ego psychology, but about Freud's radical interrogation of the psyche that leads to the borders of biology and being. We find testimony of this in a still enigmatic text of 1925, Die Verneinung (Negation). For the first time in the history of thought, even a few years before Heidegger's What Is Metaphysics?, Freud links the fate of two types of negation: the rejection proper to the drives (Ausstossung or Verwerfung) and the negativity internal to judgment. In substance, he maintains that the symbol and/or thought are a sort of negation, which itself is nothing but a transformation under certain conditions of rejection or of a disconnection proper to the drive, which is elsewhere called the "death drive".

We must now ask this question: under what conditions does the rejecting drive become symbolizing negation? All psychoanalytical research on the "paternal function" (Lacan) or the "good-enough mother" (Winnicott), to name just a couple of examples, seeks to answer this question. Melanie Klein bases the most original part of her work on the importance of this dissociating, rejecting drive, which occurs well before the appearance of the unity of the ego. This is what she calls the "schizoparanoid phase," which precedes the "depressive phase" that generates symbolism and language. The work on narcissism, borderline personalities, and so on, probes deeper into this modality of the psyche, dependent on the archaic, the instinctive, the maternal, and, beyond that, the

Journal of French and Francophone Philosophy | Revue de la philosophie française et de langue française

Vol XXII, No 2 (2014) | http://www.jffp.org | DOI 10.5195/jffp.2014.650 
extra-psychical to the point of biology or being (depending on the school of thought).

These different currents of theoretical thought in philosophy and psychoanalysis have touched on this point: through retrospective questioning that is, through inquiry or analysis - they have reached this border region of the speaking being that is psychosis.

Parallel to philosophy and psychoanalysis, not by theoretical means but by those proper to language itself, the practice of writing can attain nonsense too. By unfolding the meaning of sensations and drives, it can find its pulse in an order that is no longer "symbolic" but "semiotic." I am thinking of the de-semanticization of style through ellipses in Mallarmé or through polyphony and portmanteau words in Joyce. Through language, and linguistic overcompetence, an apparent regression is obtained to an "infantile state of language." The semiotic chora, this infra-linguistic musicality that all poetic language aims for, becomes the main objective of modern poetry, an "experimental psychosis." ${ }^{4}$ What I mean by this, is that psychosis is the work of a subject, but a subject who is on trial. It is by returning to the archaeology of the subject's unity, leading to the material of language and of thought itself, that the subject reaches the unsafe regions where this unity is annihilated.

\section{The Logical Paradoxes of Revolt}

Thoughts or writings in revolt attempt to find a representation (a language, a thought, a style) for this confrontation of the human with the unity or the limit of the law, being, and the self to which we accede in jouissance. As you know, jouissance is perceived by the old norms as an evil. Yet, insofar as jouissance is thought/written/represented, it is a passage through evil, and it is thereby perhaps the most profound way of avoiding the radical evil that results from the stoppage of representation and questioning. The permanence of contradiction, the temporariness of reconciliation, the bringing to the fore of everything that puts the very possibility of unified meaning to the test (such as the drives, the unnameable, the feminine, destruction, psychosis, etc.): this is what the culture of revolt explores.

That is to say that it announces a veritable transformation of the human deriving from the Christian eschatology of retrospection as the path to truth and intimacy. One can then see that the Freudian discovery is not a rejection of this tradition but a deepening of it all the way to the limits of conscious unity. From that starting point, the Freudian path announces a possible transformation of our culture, inasmuch as it initiates another relationship to meaning and the One.

Journal of French and Francophone Philosophy | Revue de la philosophie française et de langue française 
As you will have gathered, it is not so much in the world of action that this revolt is realized but rather in that of psychical life and its social manifestations (writing, thought, art). This revolt seems to me to manifest the crises of modern man as much as its advances. Yet, as a transformation of man's relationship to meaning, this cultural revolt intrinsically concerns the life of the city. It therefore has far-reaching political implications. In fact, it poses the question of another politics, one of permanent conflict.

I am sure you are well aware of how psychoanalysis has been attacked, denigrated and marginalized lately. While it has been the object of resistance from the outset (inevitably, insofar as it collides with the human being's desire not to know, the human being preferring sexual mystification to confronting truths that may place him in revolt), it seems the general suspicion surrounding analysis today can be explained by other causes. The conditions of modern life - with the prevalence of technology, image, speed, and so forth, all inducing stress and depression - tend to reduce psychical space and to abolish the faculty of representation. Psychical curiosity might be considered natural but turns out to be less and less natural; it yields before the demands of so-called efficiency. The unquestionable advances of the neurosciences are then ideologically valorized and championed as antidotes to psychical afflictions. Gradually, these afflictions are denied as such and reduced to their biological substrata, a neurological deficiency.

A schematic materialism claims to do without the Freudian dualism that reserved a place for initiative, autonomy, and the desire of the subject. A diehard cognitivism subsumes within the same logic both the neuronal economy and the heteronomy of psychical representations. Ideological protests of a politically correct sort promote ethnic and sexual differences while refusing the rational approaches (psychoanalysis, among them) that allow a better grasp of their singularities. By denigrating what they call an analytical universalism, these currents shift from militancy to a sectarian logic. Finally, psychoanalytical societies themselves contribute to discrediting psychoanalysis, with their fearful politics and concern for safeguarding their clinical purity or, on the contrary, for their unduly aggressive ideological, if not spiritual, orientation. As a result, they undermine the "Copernican revolution" that Freud introduced in the twentieth century and that we increasingly perceive to be one of the only ones that does not turn away from either the afflictions or the revolts of modernity.

Perhaps it is necessary to recall some of the paradoxical logics of the analytical cure to highlight the type of intimacy that analytical experience has brought to light, as modern art has, though by entirely different means.

Recall the unprecedented timelessness (Zeit-los), which no philosophy had identified before him. It does not characterize mystical nunc stans but the temporality of the unconscious. While human existence is intrinsically

Journal of French and Francophone Philosophy | Revue de la philosophie française et de langue française

Vol XXII, No 2 (2014) | http://www.jffp.org | DOI 10.5195/jffp.2014.650 
linked to time, the analytical experience reconciles us with this timelessness, which is that of the drives, and more particularly, of the death drive. Unlike any other translation or deciphering of signs, analytical interpretation emerges as a secular version of "forgiveness", in which I see not just a suspension of judgment but a giving of meaning beyond judgment, within transference and counter-transference.

Through timelessness and the revision of judgment, the analytical experience leads us to the borders of thought. Venturing into these regions is of interest to the philosopher as well as to the moralist, since the examination of thought (what is a thought, without time or without judgment?) implies an examination of judgment, of morality, and, ultimately, of the social bond.

Of particular interest are the aesthetic or literary variants of timelessness and forgiveness that the analytical experience reveals. In short, with timelessness and forgiveness we are able to revisit nothing less than our intimate depths, which appear to us as the experience of suffering. Is it not true that the various forms of "possession" of our intimacy, including the most demonic and most tragic, remain our refuge and our resistance in the face of a so-called "virtual" world where judgments are blurred or assume an archaic and barbarous form? It is precisely in imaginary experience, particularly in literature, that this intimacy is deployed, with its timelessness in its strange forgiveness.

Am I essentially pleading the case of intimate revolt as the only possible form of revolt? I am aware of the commercial dead-ends and spectacular quagmires of all the imaginary productions in which our rebellious intimacy manifests itself. There are periods when even the mystical path - this acceleration of libertarian transformations - is confined within treatments of pathology or else within spiritualist or decorative ghettos. This is one of those periods.

Faced with the invasion of the spectacle, we can still contemplate the rebellious potentialities that the imaginary can revive in our innermost depths. This is perhaps not yet a time of great works, or perhaps, for we contemporaries, they are underway but remain invisible. Nevertheless, by keeping our intimacy in revolt we can preserve the possibility of their appearance.

\section{The Need to Believe and the Desire to Know}

I have made reference to psychoanalysis above, but the revolt that seeks rebirth and constitutes the psychical life of analysands is not far removed from what every person feels when listening to his or her "inner self." Traversed by complex logics, two of its movements are familiar to you all: the need to believe and the desire to know. ${ }^{5}$

Journal of French and Francophone Philosophy | Revue de la philosophie française et de langue française 


\section{The Oceanic Feeling....}

Two psychical experiences confront the clinician with the need to believe. The first refers to what Freud, in responding to Romain Rolland, describes not without reluctance as the "oceanic feeling" in Civilization and its Discontents. This has to do with the intimate union between the Ego and the surrounding world. It is experienced as an absolute certainty of satisfaction and security as well as a loss of oneself in favor of that which surrounds and contains us, in favor of a container. This alludes to the experience of the infant that has not yet established borders between his or her Ego and the maternal body. Indisputable and indivisible, this experience is given only to "some" whose "regression can go far enough." Yet, Freud authenticates it as an original experience of the Ego. This pre- or translinguistic experience, dominated by sensation, is at the heart of belief. It is belief not in the sense of a supposition but of an unshakeable certainty. It is a sensorial plenitude and ultimate truth that the subject experiences as an excessive — both sensorial and mental, and strictly speaking, ek-static over- or super-life. Certain aesthetic works provide evidence of this, and I have recognized it quite particularly in the work of Proust. The narrator mentions dreams without imagery ("the dream of the second apartment") interwoven with pleasures and pains that "we believe" (as he specifies) unnameable. They draw upon the extreme intensity of the five senses and only a cascade of metaphors can attempt to "translate" them. The story of these dreams may be interpreted as a triumph over the endogenous autism that resides in our unconscious depths, as the psychoanalyst Frances Tustin would see it. Is the writer, then, the one who is able to succeed where the autist fails?

\section{The Psychoanalytic Approach to Believing and Knowing}

Let us take Psalm 116:10: "He' emanti ki adaber..." "My trust does not fail even when I say, 'I am completely wretched. In my terror I said, 'No human being can be relied on.'” Echoing Psalm 116, Saint Paul in his Second Letter to the Corinthians 4:13 said, "Epistevsa dio elalisa" (in Greek), "Credidi, propter locutus sum" (in Latin), "I believed and therefore I have spoken" (in English). A few lines before, the psalmist evokes God's merciful ear ("I love the Lord because he hath heard my voice and my supplications..."), the loving Other, and collects the many interpretations of the Hebrew word "ki" ("and", "because", "despite").

I understand the verse as follows: "Because You speak to me and listen to me, I believe and I speak, despite the unnamable." The context of the psalm is more explicit: it is associated with faith ("emuna" in which we hear the root "amen," faith or belief) which fills the statement with specific, indifferent and, even, deceptive meanings. Faith holds the key to the act of speech itself, even when it expresses a complaint ("I'm unhappy," "people lie to me,"

Journal of French and Francophone Philosophy | Revue de la philosophie française et de langue française

Vol XXII, No 2 (2014) | http://www.jffp.org | DOI 10.5195/jffp.2014.650 
etc.). Because I believe, I speak. I wouldn't speak if I didn't believe. To believe what I say and to continue to say it grows out of the capacity to believe in the Other and not from inevitably disappointing existential experience. But what is the nature of this "belief?"

The Latin credo comes from the Sanskrit "kredh/sraddhà" which denotes an act of "confidence" in a God, involving restitution in the form of a divine favor accorded to the faithful. It is from this root that the financial term "credit" was derived; I set down a good and await my pay.

The psychoanalytical experiences of the child and the adult attest to two crucial moments of development where the infans projects himself onto an outsider with whom he identifies: the loving father. On the one hand, there is the "oceanic feeling" of losing oneself in the maternal envelope, but also of infinitely likening oneself to the carrier wave of her protection. Isn't this what the believer feels in the grace of communion with the Divine, and that Romain Rolland asked Freud to interpret? On the other hand, and closer to our questioning of the paternal role in the religious connection, let us recall what Freud calls a "primary identification." This primary identification with the father of individual prehistory is the dawning of the symbolic outsider who replaces the fascination and the horror of the dual interdependence of the mother and child. ${ }^{6}$ This confident recognition is offered by the fatherwho-loves-the-mother and is loved by her, and I in turn devote myself to him. This changes my stammering into linguistic signs, whose value he determines.

Although these are signs of objects, they are mostly signs of my jubilations and my fears, of my early years of life. Spoken words transform my angst into "a believing expectation": Gläubige Erwartung, wrote Freud7. Loving paternal listening gives meaning to what would otherwise be an inexpressible trauma, a nameless excess of pleasure and pain. But I do not construct this primary identification, nor does the loving father who imposes it on me. The primary identification is "direct and immediate," like lightning or a hallucination. It is through the father-loving mother's sensitivity and discourse - a mother to whom I still belong and remain inseparable — that this "unification" of myself-in-another-who-is-anoutsider is imprinted in me and structures me.

Before Laius (the Oedipal father), the imaginary father recognizes me and loves me through the mother. This lets me know that I am not her but other and makes me believe that I can "believe." Freud uses the word "cathexis" (Besetzung). To believe and/or to cathect, not in him as the "object" of need or desire, but in his representation of me and in his words in the representation that I make of him and in my words. "I believed and therefore I spoke."

On this foundation alone, my need to believe is thus satisfied and offers me optimal conditions for language acquisition. This can be accompanied by

Journal of French and Francophone Philosophy | Revue de la philosophie française et de langue française 
another capacity that is both corrosive and liberating: the desire to know. Carried by this faith that lets me hear a loving/loved outsider, I burst into questions.

Who hasn't witnessed the pleasurable trance of a child asking questions? Still straddling the border between the flesh of the world and the kingdom of language, the child knows with a hallucinatory knowledge that all identity - object, person, himself, the adult's response - is a constructible-deconstructible chimera. Lacan thought that the motto for psychoanalysis should be "Scilicet": "you can know." He forgot to mention that "you can know," if and only if you believe you can know. From knowing to believing, and vice versa, such is the eternal turnstile of speakingbeing (parlêtre).

\section{Adolescence: A Syndrome of Ideality}

Whereas the child is a polymorphic pervert according to Freud who wants to know where babies come from and who Freud compares to a "laboratory researcher," the adolescent is a believer. The adolescent is not a "researcher" in a laboratory but a believer. We are all adolescents when we are enthralled by the absolute. Freud did not preoccupy himself with adolescents because he was himself a firm non-believer, perhaps the most irreligious person who ever existed. Faith implies a passion for what psychoanalysis calls an "object relation": faith is potentially fundamentalist, as is the adolescent. Romeo and Juliet are excellent examples of this. However, because the sadomasochistic nature of our drives and desires is inevitable, adolescent belief in the existence of the Ideal Object is constantly threatened.

I will assert, then, that the adolescent is a believer in the object relation and/or of its impossibility. Thus formulated, the question implies a parameter that is hard to take seriously: this parameter is ideality.

What is the ideality syndrome? The adolescent Oedipal complex is violent because it operates on the carrier wave of idealization. The adolescent whose psyche is rooted in the polymorphous perversity of the young child separates from the parental couple and replaces it with a new model. In so doing, the narcissism of the Ego, tied up with its ideals, overflows the object and gives way to the amorous passion specific to the drive-ideality connection.

The intensity of this new satisfaction is procured thanks to something not sufficiently brought out in Freudian theory. The inclusion of the object in narcissism happens in the guise of belief. The adolescent acquires the certainty that there is an absolute satisfaction. This is the certainty that he or she can erase the original and tragic Oedipus complex and rush towards a new love that will open the door to new paradises. Images, ideologies, different forms of knowledge, and existential models are all brought into

Journal of French and Francophone Philosophy | Revue de la philosophie française et de langue française

Vol XXII, No 2 (2014) | http://www.jffp.org | DOI 10.5195/jffp.2014.650 
play to shore up an idealized narcissism which unfolds over others and which surpasses all former ideals in strength. Ideality dominates the adolescent unconscious: adolescent drives and pleasure are structured not only as a language but also as an ideality.

Let me sum this up as follows. The belief that an ideal object exists (be it a partner, a profession, or a creation) is accompanied by the absolute belief that the parental couple must be surpassed and even abolished so that the adolescent subject can escape into an idealized, paradisiacal form of absolute satisfaction. The Judeo-Christian paradise is an adolescent creation. The adolescent takes pleasure in the paradise syndrome, which conversely, can also become a source of suffering if absolute ideality turns into cruel persecution. Because the adolescent believes that the other, surpassing the parental other, not only exists but provides absolute satisfaction, the adolescent believes that the Great Other - God - exists and is pleasure. The slightest disappointment of this ideality syndrome ruins paradise and leads toward delinquent conduct.

\section{Believers and Nihilists}

Insofar as adolescence is structured by idealization, we understand that it constitutes the malady of ideality. Either the adolescent lacks ideality or in a given context his or her ideality fails to adapt to the post-puberty drive and thus to the need to share with an absolutely satisfying object. Adolescent ideality is necessarily demanding and in a state of crisis, since the drive-ideality connection is constantly at risk of disintegration. Adolescent belief inexorably mixes with adolescent nihilism. Why? Because it exists (in the unconscious), yet "he" or "she" disappoints me (in reality). I have no choice but to be angry with "them" and seek revenge: vandalism is what follows. Or, because it exists (in the unconscious), yet "he" or "she" disappoints me. I have no choice but to take it out on myself: self-mutilation and self-destructive behavior follows.

Drug addiction thus abolishes consciousness but the experience of hallucinatory pleasure satisfies the belief in the absolute of orgasmic regression. Anorexic behavior breaks with the maternal line and reveals the young woman's battle against femininity. Yet, this is to the benefit of an over-investment of the "hard-lined" body, which echoes back to the fantasy of absolute spirituality. Through this fantasy, the entire body disappears in a beyond that is laden with paternal connotations.

It is here that the analyst gets caught. For, many tend to stop at the erotic or thanatic symptom forgetting ideality, which controls the symptom from the unconscious. But, how do we take into account the fact that the unconscious of the adolescent believer is constructed as a high-risk ideality?

Civilizations commonly referred to as primitive have long used initiation rites to assert symbolic authority (divine for the invisible world,

Journal of French and Francophone Philosophy | Revue de la philosophie française et de langue française 
political for this world here) and to justify the acting out of what we would qualify today as perverse by condoning initiatory sexual practices. In our own Western culture, notably in medieval Christianity, mortification rituals and excessive fasting channeled the anorexic and sadomasochistic behaviors of adolescents. In so doing, they either downplayed or glorified them.

In yet another secular way, what seems to me to be an imaginary elaboration of the adolescent crisis is the birth of the European novel shaped around the adolescent character. ${ }^{8}$ The young page serving his Lady is a recurrent trope of courtly love in which a complex range of homosexual relations, more or less fully developed, are played out. Does psychoanalysis innovate, and if so, how does it avoid the pitfall of stabilizing the couple in marriage, that temporary happy ending of the bourgeois novel? Even today, popular literature continues to draw from the narrative logic developed in the Renaissance. Even hard-core sex fails to break out of this logic and is easily assimilated into it

Compared to the various ways of dealing with adolescents that have preceded us, we might wonder whether psychoanalysis, with its emphasis on attentive listening, is innovative. And if so, how? It is the analyst's job to listen to the adolescent's need to believe and to confirm it. If adolescents come to us, it is because they need us to recognize their ideality syndrome. We must articulate and share our understanding of it, if we are to comprehend and accurately interpret the delinquent behavior of the adolescent in crisis as a source of extreme jouissance - simili-paradis. Only later should the analyst attempt to point out the negative aspects, the Oedipus or Orestes type revolt, of this behavior.

In other words, only the analyst's capacity to see the pleasure-seeking, idealizing course of adolescent drives will provide a credible and effective transference and thus metabolize the need to believe through the pleasure that comes with thinking, questioning, and analyzing. Sharing the ideality syndrome of the adolescent allows the analyst to weaken the patient's resistance and guide the adolescent through an analytical process against which the adolescent generally rebels.

The religious need, which was replaced throughout the 20th century by ideological enthusiasm, served and continues to serve as a way to authenticate the ideality syndrome. It is no coincidence that, alongside the adolescent malaise which so worries modern society (to the point of spending handsome sums to establish "youth centers/homes" for teenagers with great pomp), we see religion making a come-back, often in bastardized forms (sects) or with a fundamentalist twist (encouraging the death drive to shift into high gear in the name of an ideal). In this context, adolescence can perhaps be seen in terms of its possibilities, though this outlook is contingent on our ability to accompany the teenager's need to believe that is coextensive with the impossibility of this belief. In so doing, we would be

Journal of French and Francophone Philosophy | Revue de la philosophie française et de langue française

Vol XXII, No 2 (2014) | http://www.jffp.org | DOI 10.5195/jffp.2014.650 
better able to interpret the forms of our civilization's new malaise and this renaissance of the "need to believe." We ourselves share this need, since within us there is a perpetual adolescent.

\section{Conclusion}

To conclude, I would like to highlight the revolts we call the "suburban troubles," which are especially felt in Marseille but elsewhere as well. Aren't they due to a failure of the French model of secularism? In fact, the matter is more grave: we are below the level of the clash of religions. I think that the delinquency of "disadvantaged teens" reveals a more radical phase of nihilism. This delinquency concerns the deeper mechanisms of civilization and highlights the destruction of the pre-religious "need to believe" that constitutes the psychical life with and for others, on which I have sought to shed light today.

Adolescent gangster fundamentalism has suddenly revealed that the religious treatment of revolt has lost credibility. It is insufficient to ensure the paradisiacal aspirations of the paradoxical believer, the nihilist believer who is necessarily nihilist because pathetically idealistic - the disconnected, desocialized teenager in the ruthlessness of global migration.

Psychoanalysis speaks to this deep disorganization of the self unbound (the "I" doesn't exist, "nothing but an unbinding drive ready to go to any extreme") - and of the relationship to the other - to the point of deobjectification ("the other has no meaning or value") — where the death drive alone, the malignity of evil, triumphs. And so we find ourselves facing "radical evil" in a new way.

What is radical evil? It consists of asserting - and realizing - the superfluity of human beings: their being sentenced to death (Kant, Arendt).

Is radical evil "without reason"? Mysticism and literature both say so in their own ways. We - the political pact - cannot stop there. With the psychoanalytical experience, I do not remain content to revolt, and even less so against radical evil. I seek the logic of extreme evil so as to refine its interpretation in the transference-countertransference. We discover that, after familial disintegrations and social failures, some people - especially adolescents - succumb to the disease of ideality. They literally explode and become incapable of distinguishing good from evil, inside from outside, or subject from object. Of the two drives that exist within us - of life and of death - it is the death drive that absorbs their psychical life, sinks into blind destructiveness and finally self-destruction. The need to believe collapses within the empire of unbinding and de-objectification; this is accompanied by either a mad pleasure or the emptiness of apathy.

Here, we must make an important distinction. Yes, there does exist an evil that comes from the clash of values. Values themselves are produced by

Journal of French and Francophone Philosophy | Revue de la philosophie française et de langue française 
divergent or competing libidinal interests and underlie our conceptions of good and evil. Religious man and moral man are constituted of these: regardless of whether they are more or less guilty and enraged, they experience them, worry about them, and hope to elucidate them so that they can listen to one another rather than kill one another.

In addition to this type of evil, however, there is an extreme evil, which sweeps away the meaning of the distinction between good and evil and thereby destroys the possibility of accessing the other's existence, meaning, and self. These extreme states do not take refuge in hospitals or on the psychoanalyst's couch, instead they unfold in socio-political catastrophes and in the abjection of exterminations such as the Holocaust, that horror which defies explanation and reason. But the new forms of extreme evil are spreading in a globalized world, in the wake of maladies of ideality.

And it is from this diagnosis that the audacity of psychoanalytic care springs and seeks to be more than a "comprehensive moralism." It places the analyst at the unsustainable intersection where this disobjectalisationobjectalisation moves about threateningly, and yet can initiate a restructuring. This is our challenge, after the discovery of the death drive and the malignant potential of the psychic apparatus that dwells within its ability to produce maladies of ideality. These diseases of the soul destroy both the need to believe and the desire to know, such that the human being is rendered incapable of investing himself and establishing relationships. Dispossessed of a "self" and lacking a sense of the other, one wanders aimlessly in the absence of a "world", in a non-world with neither "good" nor "evil," nor "value" of any kind.

Is it possible to push analytical listening to the borders of Homo Sapiens and to continue practicing psychoanalysis in these conditions? The French Republic is facing a historic challenge. Will it be able to confront this crisis of the need to believe and the desire to know, which is no longer contained by the lid of religion and which touches the very depths of the bond between human beings? The anguish paralyzing the country in these times of excess and against the backdrop of economic and social crisis expresses our incertitude before this colossal issue. Can we mobilize all of our resources police and economic, not to mention those which give us knowledge of souls - to care for the harrowing malady of ideality that is engulfing us and which is expressed by adolescents from good neighborhoods and even more so in lawless areas? Can we care for them with the necessary delicacy and attentiveness, with an appropriate education and with the needed generosity? Interpreted as such, the "crisis of the youth" who call out for God and who are beset by the malignancy of evil cannot not concern us.

I have attempted to tell you how much it concerns me. Am I optimistic? Perhaps too optimistic? I would define myself rather as an energetic pessimist who appreciates only an active intelligence in thought, or the

Journal of French and Francophone Philosophy | Revue de la philosophie française et de langue française

Vol XXII, No 2 (2014) | http://www.jffp.org | DOI 10.5195/jffp.2014.650 
timeliness of intelligence. And so I ask: What is one to do? What are we to do? To quote Nietzsche: "Put a big question mark in the place of heavy seriousness," that is, in God's place. "Transvalue" (Umwertung aller werte) values, passions, needs to believe and desires to know. Do not give up in face of evil, not even in face of extreme evil. But patiently pursue the search - certainly not for who knows what utopian balance, but rather the search for a path to that fragile point described by Pascal: "Whosoever would find the secret of rejoicing in the good without troubling himself with its contrary evil would have hit the point. It is perpetual motion." And what if the revolt we lack today is precisely this "point", this "perpetual motion", toward the "secret of rejoicing in the good without troubling oneself with its contrary evil"? What if it is a certain inner experience?

1 Julia Kristeva, Intimate Revolt: the Powers and Limits of Psychoanalysis (New York: Columbia University Press, 2002). Julia Kristeva, The Sense and Non-Sense of Revolt, trans. Jeanine Herman (Columbia University Press, 2001).

${ }^{2}$ The ancient forms wel and welu, refer to a voluntary, artisanal act, leading to the denomination of technical objects that protect and encase. They evolve toward the sense of 'return', 'uncovering/ unravelling', 'the circular movement of the planets', the Italian 'volte-face', ('about face'), 'vaudeville' in French, the 'volume' of a book, and the Swedish car 'Volvo'.

${ }^{3}$ Hannah Arendt, The Origins of Totalitarianism (New York: Harcourt Brace, 1951).

4 Julia Kristeva, Revolution in Poetic Language, trans. Margaret Waller (New York: Columbia University Press, 1984).

5 See Julia Kristeva, "The Big Question Mark," in This Incredible Need to Believe, trans. Beverley Bie Brahic (New York: Columbia, 2013), vii-xvi.

${ }^{6}$ See Sigmund Freud, The Ego and the Id (New York: Norton, 1923).

${ }^{7}$ See Sigmund Freud, Résultats, idées, problèmes, vol. I (1890-1920) (Paris: PUF, 1998), 8.

${ }^{8}$ See Julia Kristeva, "The Adolescent Novel," in New Maladies of the Soul, trans. Ross Guberman (New York: Columbia University Press, 1997), 135-153. 